\title{
EFFECTS OF INTESTINAL MICRO-ORGANISMS ON FLUID AND ELECTROLYTE TRANSPORT IN THE JEJUNUM OF THE RAT
}

\author{
P. Thelen, Valerie Burke and M. Gracey \\ Gastroenterological Research Unit, Princess Margaret Children's Medical \\ Research Foundation, Perth, Western Australia
}

Toxins produced by Escherichia coli and Vibrio cholerae are well known to affect intestinal fluid and electrolyte transport (Pierce, Greenough and Carpenter, 1971; Pierce and Wallace, 1972; Finkelstein, 1976). Similar effects have been described with Clostridium perfringens (Duncan and Strong, 1969), staphylococcal enterotoxin B (Sussman, Ryan and Shields, 1970) and Shigella flexneri and Shigella sonnei (Keusch and Jacewicz, 1977). Several other Gramnegative enteric organisms have also been shown to be enterotoxigenic including certain strains of Klebsiella spp. and Enterobacter spp. (Klipstein et al., 1973) as well as of Citrobacter spp., Proteus spp., Aeromonas spp., Serratia spp. and Pseudomonas spp. (Wadström et al., 1976). However, studies of enterotoxin production in organisms other than those of Gram-negative species have been limited.

Reports from South East Asia, Africa and the Caribbean (Mata et al., 1972; Gracey et al., 1973; Heyworth and Brown, 1975; Rowland and McCollum, 1977) have shown the upper intestinal secretions of malnourished children to be contaminated with excessive numbers of a variety of microorganisms. Many of these are not usually considered to be enteropathogenic, but we have already shown that jejunal sugar absorption is impaired by several of these organisms (Gracey et al., 1975; Burke, Houghton and Gracey, 1977). In view of this, and because transport of fluid and electrolytes in the upper intestine is known to be influenced by Vibrio cholerae and cholera toxin (McGonagle et al., 1969; Banwell et al., 1970) it seemed appropriate to investigate whether similar effects might be caused by a wider spectrum of intestinal organisms. The present study was concerned with the effect of such organisms on the jejunal transport of water and electrolytes in live rats.

\section{MATERIALS AND METHODS}

Strains. Except for the enterotoxigenic strain B7A of Escherichia coli, which was isolated from an adult, all micro-organisms used were isolated from the upper intestinal contents of malnourished Indonesian children (Gracey et al., 1975). The isolates comprised individual strains of the following species: Staphylococcus epidermidis, Streptococcus faecalis, Salmonella paratyphi B, Shigella sonnei, Klebsiella pneumoniae, Candida albicans, Candida tropicalis; in addition two Escherichia coli isolates were tested, one belonging to serotype 055 and one non-enteropathogenic strain.

Received 6 Dec. 1977; revised version accepted 6 Mar. 1978.

J. MED. MICROBIOL.-VOL. 11 (1978) 
Preparation of culture filtrates. Bacteria and yeasts that had been stored at $-20^{\circ} \mathrm{C}$ were grown under aerobic conditions as pure cultures in $100-\mathrm{ml}$ volumes of a modified phosphate-buffered peptone medium containing 1\% Bacto-Peptone (Difco Laboratories, Michigan, Detroit, USA) in 250-ml Erlenmeyer flasks. After incubation at $37^{\circ} \mathrm{C}$ in a shaking waterbath at 50 oscillations per min. for $18 \mathrm{~h}$, cultures were checked for purity and total cell counts were made by microscopy. For growth of Candida spp., the $p \mathrm{H}$ of the medium was lowered to $6 \cdot 0$. Cell-free preparations were made by centrifuging the cultures at 3000 r.p.m. for $30 \mathrm{~min}$. and filtering the supernate through a Millipore type HA filter (Millpore Corp., Bedford, Massachusetts, USA). For all control experiments, uninoculated medium was treated identically.

Perfusion fluid. The phosphate buffer $(p \mathrm{H} 7.25)$ contained $\mathrm{KH}_{2} \mathrm{PO}_{4} 0.5988 \mathrm{~g}$, $\mathrm{Na}_{2} \mathrm{HPO}_{4} 7.0423 \mathrm{~g}$ and $\mathrm{NaH}_{2} \mathrm{PO}_{4} 1.04232 \mathrm{~g}$ per litre. Immediately before the experiments, sodium chloride $1.753 \mathrm{~g}$ per litre and mannitol $9 \mathrm{~g}$ per litre were added to simulate physiological and isotonic conditions. Osmolality of the test solutions was 290 (standard error [SE] \pm 5 ) mosM.

Phenol red $5 \mu \mathrm{g}$ per $\mathrm{ml}$ (British Drug Houses, London) was added to the cell-free filtrate as a non-absorbable marker for measurements of water transport. Recovery of phenol red was $99 \%(\mathrm{SE} \pm 1 \cdot 58)$.

Absorption experiments. Adult male rats (Wistar inbred albino) weighing 200-250 g were obtained from a long-established colony in the University of Western Australia. They were fasted overnight, but allowed water ad libitum before the experiment.

Rats were anaesthetised by the intraperitoneal injection of urethane (ethyl carbamate) ( $1 \mathrm{~g}$ per $\mathrm{kg}$ body weight), and surgery was carried out under a heating lamp to maintain the body temperature.

Two cannulae were introduced through the gut wall, one at each end of an intact segment of jejunum approximately $20 \mathrm{~cm}$ in length, and tied in position with black silk. The gut segment was washed with $3 \mathrm{ml}$ of the buffer solution described above, and then drained by gently blowing air through it.

The segment was replaced in the abdominal cavity and perfused with the undiluted culture filtrate at $2 \mathrm{ml}$ per $\mathrm{h}$. After equilibration for $30 \mathrm{~min}$., perfusate was collected over a period of $60 \mathrm{~min}$. At the end of the perfusion, the test segment was drained and washed with $5 \mathrm{ml}$ of buffer, and its length was measured under the tension of a standard weight.

A second series of perfusion experiments was designed to investigate the relationship between net water and electrolyte flux and time of exposure to the cell-free supernate. The jejunal segment was prepared as described above and perfused at a rate of $10 \mathrm{ml}$ per h. A 10 -min. period was allowed for equilibration and samples were then collected after a further 15, 30 and $60 \mathrm{~min}$. After $60 \mathrm{~min}$. the segment was drained, washed, and measured as before.

Biochemical assays. Sodium and potassium were determined in initial and final solutions by flame photometry, and chloride by coulometric titration. Phenol red was determined spectrophotometrically at $560 \mathrm{~nm}$; samples and washings were centrifuged and $0.5-\mathrm{ml}$ volumes of fluid were made alkaline with $1 \mathrm{ml}$ of $1 \mathrm{~N} \mathrm{NaOH}$. In the experiments in which samples were taken at 15, 30 and $60 \mathrm{~min}$., the 15- and 30-min. values were corrected for the amount of phenol red obtained in the washing at the end of the $60-\mathrm{min}$. period.

Expression of results. Net water flux is expressed as change in volume per $\mathrm{cm}$ of intestine per $\mathrm{h}$ and for sodium, potassium and chloride in $\mu$.moles per $\mathrm{cm}$ of intestine per $\mathrm{h}$. For statistical calculations Student's $t$ test was used, after taking $\log _{10}$ of the observed values, as variance was proportional to the size of the observations. A level of $P<0.05$ was considered significant.

\section{RESULTS}

Net water flux. With the exception of the Streptococcus faecalis isolate, the non-enteropathogenic strain of Escherichia coli and the Salmonella paratyphi $B$ isolate, all the organisms studied were associated with a decrease in net movement of water out of the jejunal lumen. As shown in table I, net water 
TABLE I

Effect of cell-free culture filtrates on net flux of water after perfusion* of rat jejunum in vivo for $1 \mathrm{~h}$

\begin{tabular}{|c|c|c|c|}
\hline Organism & $\begin{array}{l}\text { Number of } \\
\text { experiments }\end{array}$ & $\begin{array}{c}\text { Mean } \\
\text { net water } \\
\text { flux (ml per } \\
\text { cm perh) from } \\
\text { lumen (SE in } \\
\text { parenthesis) }\end{array}$ & $\begin{array}{c}\text { Significance } \\
\text { (P) } \\
\text { of difference } \\
\text { from } \\
\text { controls }\end{array}$ \\
\hline $\begin{array}{l}\text { Gram-positive cocci } \\
\text { Staphylococcus epidermidis } \\
\text { Streptococcus faecalis }\end{array}$ & $\begin{array}{l}12 \\
12\end{array}$ & $\begin{array}{l}0.007(0.003) \\
0.049(0.001)\end{array}$ & $\underset{\text { NS }}{<0.0005}$ \\
\hline $\begin{array}{l}\text { Enterobacteriaceae } \\
\text { Non-pathogenic E. coli } \\
\text { E. coli } 055 \\
\text { E. coli B7A } \\
\text { Salmonella paratyphi B } \\
\text { Shigella sonnei } \\
\text { Klebsiella pneumoniae }\end{array}$ & $\begin{array}{r}6 \\
9 \\
12 \\
12 \\
12 \\
11\end{array}$ & $\begin{array}{c}0.051(0.002) \\
-0.047(0.003) \dagger \\
0.023(0.001) \\
0.042(0.001) \\
0.020((0.001) \\
0.001(0.002)\end{array}$ & $\begin{array}{c}\text { NS } \\
<0.005 \\
<0.0025 \\
\text { NS } \\
<0.005 \\
<0.0025\end{array}$ \\
\hline $\begin{array}{l}\text { Candida species } \\
\text { Candida albicans } \\
\text { Candida tropicalis }\end{array}$ & $\begin{array}{l}11 \\
11\end{array}$ & $\begin{array}{l}0.022(0.002) \\
0.019(0.001)\end{array}$ & $\begin{array}{l}<0.0025 \\
<0.0005\end{array}$ \\
\hline Controls & 10 & $0.041(0.001)$ & \\
\hline
\end{tabular}

* Perfusion flow rate $=2 \mathrm{ml}$ per $\mathrm{h}$.

+ Negative value represents secretion into the intestinal lumen.

NS = Not significant.

flux was affected by filtrates of the isolates of Staphylococcus epidermidis (identified by lack of DNAse and coagulase), Escherichia coli 055, Escherichia coli B7A, Shigella sonnei, Klebsiella pneumoniae, Candida albicans and Candida tropicalis. However, only Escherichia coli 055 produced net secretion of water into the intestinal lumen during the 1 -h period of perfusion.

This pattern of net water movement was consistent after perfusion for 15 , 30 and $60 \mathrm{~min}$., but there was a decrease in net water flux with time for all organisms except the non-enteropathogenic Escherichia coli and the Streptococcus faecalis and Salmonella paratyphi $B$ isolates. After $15 \mathrm{~min}$., differences from control values were significant for all other organisms, and they increased with time. These results are shown in table II.

Net sodium movement. Table III shows the net jejunal sodium flux after perfusion for $60 \mathrm{~min}$. Changes in net sodium flux paralleled the effects of net water movement for each organism studied. The values for sodium movement out of the lumen were significantly less than the control values $(P<0.005)$ for the isolates of Staphylococcus epidermidis, Escherichia coli 055, Escherichia coli B7A, a Klebsiella sp., Candida albicans and Candida tropicalis. Although the Shigella sonnei isolate caused a decrease in net sodium flux out of the lumen, the difference from the control values was not statistically significant. Secretion of sodium into the intestinal lumen was found with the Escherichia coli 055 and Klebsiella pneumoniae isolates. 
TABLE II

Effect of cell-free culture filtrates on net water flux after perfusion* of rat jejunum in vivo for 15, 30 and $60 \mathrm{~min}$.

\begin{tabular}{|c|c|c|c|c|c|c|}
\hline \multirow[t]{2}{*}{ Organism } & \multicolumn{6}{|c|}{$\begin{array}{l}\text { Net water flux (ml per } \mathrm{cm} \text { intestine per } \mathrm{h} \text { ) from lumen } \\
\text { (SE in parenthesis) at }\end{array}$} \\
\hline & \multicolumn{2}{|c|}{$15 \mathrm{~min}}$. & \multicolumn{2}{|c|}{$30 \mathrm{~min}}$. & \multicolumn{2}{|c|}{$60 \mathrm{~min}}$. \\
\hline $\begin{array}{l}\text { Gram-positive cocci } \\
\text { Staphylococcus } \\
\text { epidermidis } \\
\text { Streptococcus faecalis }\end{array}$ & $\begin{array}{l}0.020 \\
0.062\end{array}$ & $\begin{array}{l}(0.001) \\
(0.003)\end{array}$ & $\begin{array}{l}0.018 \\
0.056\end{array}$ & $\begin{array}{l}(0.001) \\
(0.002)\end{array}$ & $\begin{array}{l}0.016 \\
0.053\end{array}$ & $\begin{array}{l}(0.003) \\
(0.002)\end{array}$ \\
\hline $\begin{array}{l}\text { Enterobacteriaceae } \\
\text { Non-pathogenic } E \text {. coli } \\
\text { E. coli } 055 \\
\text { E. coli B7A } \\
\text { Salmonella paratyphi B } \\
\text { Shigella sonnei } \\
\text { Klebsiella pneumoniae }\end{array}$ & $\begin{array}{l}0.058 \\
0.022 \\
0.034 \\
0.063 \\
0.022 \\
0.018\end{array}$ & $\begin{array}{l}(0.003) \\
(0.002) \\
(0.002) \\
(0.004) \\
(0.001) \\
(0.001)\end{array}$ & $\begin{array}{l}0.060 \\
0.015 \\
0.025 \\
0.048 \\
0.012 \\
0.008\end{array}$ & $\begin{array}{l}(0.002) \\
(0.001) \\
(0.002) \\
(0.003) \\
(0.002) \\
(0.001)\end{array}$ & $\begin{array}{r}0.058 \\
-\mathbf{0 . 0 3 3} \\
\mathbf{0 . 0 1 3} \\
\mathbf{0 . 0 4 9} \\
\mathbf{0 . 0 0 5} \\
\mathbf{0 . 0 0 1}\end{array}$ & $\begin{array}{l}(0.004) \\
(0.002) \\
(0.001) \\
(0.001) \\
(0.001) \\
(0.004)\end{array}$ \\
\hline $\begin{array}{l}\text { Candida species } \\
\text { Candida albicans } \\
\text { Candida tropicalis }\end{array}$ & $\begin{array}{l}0.039 \\
0.041\end{array}$ & $\begin{array}{l}(0.003) \\
(0.003)\end{array}$ & $\begin{array}{l}0.031 \\
0.029\end{array}$ & $\begin{array}{l}(0.001) \\
(0.002)\end{array}$ & $\begin{array}{l}0.029 \\
0.022\end{array}$ & $\begin{array}{l}(0.002) \\
(0.001)\end{array}$ \\
\hline Controls & 0.055 & $(0.003)$ & 0.055 & $(0.001)$ & 0.051 & $(0.001)$ \\
\hline
\end{tabular}

* Perfusion flow rate $=10 \mathrm{ml}$ per $\mathrm{h}$.

Figures in bold type are significantly different $(\mathrm{P}<0.01)$ from control values.

Net potassium movement. Net potassium flux followed the same pattern as sodium flux, in that decreased movement out of the jejunal lumen occurred with the Candida albicans and Candida tropicalis isolates. The decreased potassium flux found with the Shigella sonnei isolate was not significantly different from the control values. Secretion of potassium into the intestinal lumen was seen with the isolates of Escherichia coli 055, Escherichia coli B7A, Klebsiella pneumoniae and Candida tropicalis.

\section{Discussion}

Decreased net movement out of the intestinal lumen or actual secretion of water, sodium or potassium into the intestinal lumen was found in intestinal perfusion experiments in live rats with culture filtrates of single isolates of Staphylococcus epidermidis, Escherichia coli 055, Escherichia coli B7A, Shigella sonnei, a Klebsiella sp., Candida albicans and Candida tropicalis. The isolates of Streptococcus faecalis, non-enteropathogenic Escherichia coli and Salmonella paratyphi $B$ did not have this effect.

Enterotoxins that affect intestinal movement of water and electrolytes are well known to be produced by enteropathogenic Escherichia coli (Guerrant et al., 1973) such as the isolates (055 and B7A) that we examined (Du Pont $e$ al., 1971). Shigella sonnei (Keusch and Jacewicz, 1977) and Klebsiella spp. 
TABLE III

Effect of cell-free culture filtrates on net intestinal flux of sodium and potassium after perfusion of rat jejunum in vivo for $1 \mathrm{~h}$

\begin{tabular}{|c|c|c|c|c|}
\hline \multirow{2}{*}{ Organism } & \multicolumn{4}{|c|}{$\begin{array}{l}\text { Mean net ion flux ( } \mu \text {.moles per } \mathrm{cm} \text { intestine per } \mathrm{h} \text { ) } \\
\text { from lumen (SE in parenthesis) }\end{array}$} \\
\hline & \multicolumn{2}{|c|}{ Sodium } & \multicolumn{2}{|c|}{ Potassium } \\
\hline $\begin{array}{l}\text { Gram-positive cocci } \\
\text { Staphylococcus epidermidis } \\
\text { Streptococcus faecalis }\end{array}$ & $\begin{array}{l}2 \cdot 41 \\
7 \cdot 27\end{array}$ & $\begin{array}{l}(0 \cdot 21) \\
(0 \cdot 13)\end{array}$ & $\begin{array}{l}0 \cdot 01 \\
0 \cdot 20\end{array}$ & $\begin{array}{l}(0.008) \\
(0.004)\end{array}$ \\
\hline $\begin{array}{l}\text { Enterobacteriaceae } \\
\text { Non pathogenic } \text { E. coli } \\
\text { E. coli } 055 \\
\text { E. coli } \mathrm{B} 7 \mathrm{~A} \\
\text { Salmonella paratyphi } B \\
\text { Shigella sonnei } \\
\text { Klebsiella pneumoniae }\end{array}$ & $\begin{array}{r}\mathbf{6 . 4 5} \\
-\mathbf{5 . 2 3} \\
\mathbf{2} \cdot 73 \\
5.44 \\
5.89 \\
-0.34\end{array}$ & $\begin{array}{l}(0.14) \\
(0.13) \\
(0.12) \\
(0 \cdot 16) \\
(0.22) \\
(0.30)\end{array}$ & $\begin{array}{r}0.18 \\
-0.33 \\
-0.06 \\
0.12 \\
0.11 \\
-0.13\end{array}$ & $\begin{array}{l}(0.004) \\
(0.006) \\
(0.006) \\
(0.009) \\
(0.008) \\
(0.002)\end{array}$ \\
\hline $\begin{array}{l}\text { Candida species } \\
\text { Candida albicans } \\
\text { Candida tropicalis }\end{array}$ & $\begin{array}{l}3 \cdot 12 \\
0 \cdot 41\end{array}$ & $\begin{array}{l}(0 \cdot 16) \\
(0 \cdot 12)\end{array}$ & $\begin{array}{r}0.05 \\
-0.13\end{array}$ & $\begin{array}{l}(0.009) \\
(0.01)\end{array}$ \\
\hline Controls & $6 \cdot 16$ & $(0 \cdot 11)$ & 0.29 & $(0.08)$ \\
\hline
\end{tabular}

Figures in bold type are significantly $(\mathbf{P}<0.05)$ less than the control values.

(Klipstein et al., 1973) have also been shown to produce an enterotoxin. These organisms might therefore have been expected to affect net water flux in our experiments. Secretion of fluid was seen only with Escherichia coli 055 during the period of perfusion, but isolates of Escherichia coli B7A, Shigella sonnei and Klebsiella spp. were associated with a decrease in net water movement out of the lumen. Failure to demonstrate net secretion of fluid is probably related to the time necessary for the toxins to act, and this has been variously estimated with different experimental methods. With cholera toxin, the time lag has been variously reported to be $4 \mathrm{~h}$ (Leitch, Iwert and Burrows, 1966), $30 \mathrm{~min}$. (Swallow, Code and Freter, 1968) and $15 \mathrm{~min}$. (Carpenter and Greenough, 1968). Field (1971) has shown that cyclic AMP causes an increase in intestinal short-circuit current within a few minutes, but the effect of cholera enterotoxin, while apparently related, is delayed. Perfusion of jejunal segments in the rabbit demonstrated an effect on net fluid movement $10 \mathrm{~min}$. after exposure to cholera toxin (McGonagle et al., 1969) and the difference from control values increased with time. This is similar to the results of our perfusion studies. However, McGonagle et al. (1969) reported secretion of fluid into the lumen during this period; in our experiments there was a reduction in the net flux out of the lumen with all organisms tested except for (a) the isolates of Streptococcus faecalis, Salmonella paratyphi $B$ and a non-enteropathogenic Escherichia coli, which had no effect on net water movement, and (b) the Escherichia coli 055 isolate, which produced secretion of fluid. This difference between our findings 
and those of McGonagle et al. (1969) is probably due to a difference in technique. McGonagle et al. (1969) used dilution of phenol red in the fluid collected from the jejunal segment as the measure of net fluid movement, but did not comment on their recovery of the marker. With the same method of measurement, all specimens collected from the jejunal segment in our experiments with the organisms affecting net water flux showed dilution of phenol red; they would thus be considered to have shown secretion of fluid into the intestinal lumen. By washing out the segment at the end of the perfusion study and appropriately correcting the phenol red value found in the perfusion fluid, the apparent dilution of perfusate proved to represent a reduction in water movement out of the lumen. If this step is omitted, our results show the same pattern as those of McGonagle et al. (1969). Enterotoxigenic strains of Escherichia coli (Pierce and Wallace, 1972), Shigella spp. (Keusch and Jacewicz, 1977) and Klebsiella spp. (Klipstein et al., 1973) have been described, and our results are consistent with these reports. However, a Staphylococcus epidermidis isolate and two species of Candida also affected net fluid and electrolyte flux in a similar way. The effects of cell-free filtrates of these organisms on water and electrolyte movement may be related to the production of enterotoxins or to the elaboration of other metabolic by-products. This is perhaps particularly surprising with Staphylococcus epidermidis, but the strain used was identified on the basis of lack of DNAse and coagulase, and could not have been confused with Staphylococcus aureus, which is known to produce enterotoxin (Sussman, Ryan and Shields, 1970).

We have previously found that cell-free supernates from cultures of several organisms isolated from the upper intestinal tract of malnourished children decreased absorption of monosaccharides (Burke, Houghton and Gracey, 1977). This effect on sugar transport is not always associated with an effect on net water movement. For example sugar absorption was impaired by the Streptococcus faecalis isolate, but water flux was not affected, while the Escherichia coli 055 isolate had a striking effect on water movement, but did not inhibit sugar absorption. However, the Candida albicans and Candida tropicalis isolates affected both sugar and water transport. These observations suggest that more than one metabolite or "toxin" is involved in producing these effects on intestinal transport.

It is not known whether such factors are produced in vivo but the finding that organisms isolated from the upper intestine of malnourished children may affect sugar and water transport in the small bowel is potentially important in understanding the pathogenesis of diarrhoea-a major factor in the ill health of malnourished children. Our results indicate that overgrowth of organisms in the small intestine should be considered as possibly contributing to diarrhoea, even when they are not recognised enteric pathogens.

\section{SUMMARY}

Culture filtrates of micro-organisms isolated from the upper intestinal secretions of malnourished children and grown in pure culture were shown to 
impair the intestinal absorption of water and electrolytes in live rats. Decreased net movement out of the intestinal lumen, or actual secretion of water, sodium or potassium into the intestinal lumen, was found with culture filtrates of single isolates of Staphylococcus epidermidis, Escherichia coli 055, Escherichia coli B7A, Shigella sonnei, Klebsiella pneumoniae, Candida albicans and Candida tropicalis. These organisms have been found to contaminate upper intestinal secretions in malnourished children and it is suggested that the effects observed in these experiments might be relevant to the production of the diarrhoea that is a dominant clinical feature of childhood malnutrition.

We are grateful to Dr Heinz Menge, Professor E. O. Riecken and Dr J. W. L. Robinson for advice and encouragement and to Penelope Ostergaard, Jan Beaman and Jayne Blakemore for expert technical assistance. We also thank Mr Garth Wilson and his staff for help with biochemical assays. One of us (P. T.) took part in this work during a student elective-study term from the University of Marburg, West Germany.

\section{REFERENCES}

BANwell, J. G., et al. 1970. Intestinal fluid and electrolyte transport in human cholera. J. clin. Invest., 49, 183.

Burke, V., Houghton, M. AND Gracey, M. 1977. Effect of enteric micro-organisms on intestinal sugar and fatty acid absorption. Aust. J. exp. Biol. med Sci., 55, 423.

CARPENTER, C. C. J. AND GREENOUGH, W. B. 1968. Response of the canine duodenum to intraluminal challenge with cholera exotoxin. J. clin. Invest., 47, 2600.

Duncan, C. L. AND Strong, D. H. 1969. Ileal loop fluid accumulation and production of diarrhea in rabbits by cell-free products of Clostridum perfringens. J. Bact., $100,86$.

Du Pont, H. L., Formal, S. B., Hornick, R. B., SnYder, M. J., Libonati, J. P., Sheahan, D. G., La Brec, E. H. AND Kalas, J. P. 1971. Pathogenesis of Escherichia coli diarrhea. N. Engl.J. Med., 285, 1.

FIELD, M. 1971. Intestinal secretion: effect of cyclic AMP and its role in cholera. N. Engl. J. Med., 284, 1137.

FINKELSTEIN, R. A. 1976. Progress in the study of cholera and related enterotoxins. In Mechanisms of bacterial toxicology, edited by A. W. Bernheimer, New York, p. 53.

Gracey, M., Burke, V., Thomas, J. A. AND Stone, D. E. 1975. Effect of micro-organisms isolated from the upper gut of malnourished children on intestinal sugar absorption in vivo. Am. J. clin. Nutr., $28,841$.

Gracey, M., Suharjono, Sunoto And Stone, D. E. 1973. Microbial contamination of the gut: another feature of malnutrition. Am. J. clin. Nutr., 26, 1170.

Guerrant, R. L., Ganguly, U., Casper, A. G. T., Moore, E. J., Pierce, N. F. and CARPENTER, C. C. J. 1973. Effect of Escherichia coli on fluid transport across canine small bowel: mechanism and time-course with enterotoxin and whole bacterial cells. J. clin. Invest., 52, 1707.

HEYWORTH, B. AND BROWN, J. 1975. Jejunal microflora in malnourished Gambian children. Archs Dis. Childh., 50, 27.

KeUSCH, G. T. AND JACEWICZ, M. 1977. The pathogenesis of Shigella diarrhea. VI. Toxin and antitoxin in Shigella flexneri and Shigella sonnei infections in humans. J. infect. Dis., 135, 552.

Kutpstein, F. A., Holdeman, L. V., Corcino, J. J. AND Moore, W. E. C. 1973. Enterotoxigenic bacteria in tropical sprue. Ann. intern. Med., 79, 632 .

LeITCH, G. J., IWERT, M. E. AND BuRRows, W. 1966. Experimental cholera in the rabbit ligated ileal loop: toxin induced water and ion movement. J. infect. Dis., 116, 303.

Mata, L. J., Jimenez, F., Cordon, M., Rosales, R., Prera, E., Schneider, R. E. and VITER, F. 1972. Gastrointestinal flora of children with protein calorie malnutrition. Am. J. clin. Nutr., 25, 1118. 
McGonagle, T. J., Serebro, H. A., Iber, F. L., Bayless, T. M. AND Hendrix, T. R. 1969. Time of onset of action of cholera toxin in dog and rabbit. Gastroenterology, 57, 5.

Pierce, N. F., Greenough, W. B. and Carpenter, C. C. J. JR 1971. Vibrio cholerae enterotoxin and its mode of action. Bact. Rev., 35, 1.

Pierce, N. F. and Wallace, C. K. 1972. Stimulation of jejunal secretion by crude $E$. coli enterotoxin. Gastroenterology, 63, 439.

Rowland, M. G. M. AND McCollum, J. P. K. 1977. Malnutrition and gastroenteritis in The Gambia. Trans. R. Soc. trop. Med. Hyg., 71, 199.

Sussman, M., Ryan, C. AND Shields, R. 1970. Effect of staphylococcal enterotoxin upon the intestinal handling of water and electrolytes. Br. J. Surg., 57, 391.

Swallow, J. H., Code, C. F. AND Freter, R. 1968. Effect of cholera toxin on water and ion fluxes in the canine bowel. Gastroenterology, 54, 35.

Wadström, T., Aust-Ketris, A., Habte, D., Holmgren, J., Meeuwisse, G., Möllby, R. AND SöDERLIND, O. 1976. Enterotoxin-producing bacteria and parasites in stools of Ethiopian children with diarrhoeal disease. Archs Dis. Childh., 51, 865. 